NBER WORKING PAPER SERIES

EVALUATING THE IMPACT OF TECHNOLOGY DEVELOPMENT FUNDS IN EMERGING ECONOMIES: EVIDENCE FROM LATIN AMERICA

\author{
Bronwyn H. Hall \\ Alessandro Maffioli \\ Working Paper 13835 \\ http://www.nber.org/papers/w13835
NATIONAL BUREAU OF ECONOMIC RESEARCH
1050 Massachusetts Avenue
Cambridge, MA 02138
March 2008

This paper is part of the project: "IDB's Science and Technology Programs: An Evaluation of the Technology Development Funds (TDF) and Competitive Research Grants (CRG)," by the Office of Evaluation and Oversight (OVE) of the Inter-American Development Bank (IDB). We are grateful to Bertha Briceño and Diego Ubfal, who worked on the OVE evaluation project and to Pierre Mohnen, Inder Ruprah and Yuri Soares for useful discussions as well as to two anonymous referees. The first author thanks the Institute of Innovation Research, Hitotsubashi University, for hospitality. The findings and interpretation of the authors do not necessarily represent the views of Inter-American Development Bank or the National Bureau of Economic Research.

NBER working papers are circulated for discussion and comment purposes. They have not been peerreviewed or been subject to the review by the NBER Board of Directors that accompanies official NBER publications.

(C) 2008 by Bronwyn H. Hall and Alessandro Maffioli. All rights reserved. Short sections of text, not to exceed two paragraphs, may be quoted without explicit permission provided that full credit, including (C) notice, is given to the source. 
Evaluating the Impact of Technology Development Funds in Emerging Economies: Evidence from Latin America

Bronwyn H. Hall and Alessandro Maffioli

NBER Working Paper No. 13835

March 2008

JEL No. O32,O38

\begin{abstract}
Evaluations of government Technology Development Funds (TDF) in Argentina, Brazil, Chile and Panama are surveyed. All the evaluations were done at the recipient (firm) level using data from innovation surveys, industrial surveys, and administrative records of the granting units, together with quasi-experimental econometric techniques to minimize the effects of any selection bias. TDF effectiveness is found to depend on the financing mechanism used, on the presence of non-financial constraints, on firm-university interaction, and on the characteristics of the target beneficiaries. Four levels of potential impact were considered: R\&D input additionality, behavioural additionality, increases in innovative output, and improvements in performance. The evidence suggests that TDF do not crowd out private investment and that they positively affect R\&D intensity. In addition, participation in TDF induces a more proactive attitude of beneficiary firms towards innovation activities. However, the analysis does not find much statistically significant impact on patents or new product sales and the evidence on firm performance is mixed, with positive results in terms of firm growth, but little corresponding positive impact on measures of firm productivity, possibly because the horizon over which the evaluation was conducted was too short.
\end{abstract}

Bronwyn H. Hall

Department of Economics

549 Evans Hall

UC, Berkeley

Berkeley, CA 94720-3880

and NBER

bhhall@nber.org

Alessandro Maffioli

Inter-American Development Bank

Office of Evaluation and Oversight

1300 New York Ave. NW

Washington, DC 20577

alessandrom@iadb.org 


\title{
Evaluating the Impact of Technology Development Funds in Emerging Economies: Evidence from Latin-America
}

\author{
Bronwyn H. Hall ${ }^{\#}$ and Alessandro Maffioli ${ }^{*}$
}

\section{Introduction}

In recent years the role of Science and Technology (S\&T) in growth has gained preeminence in the public policy dialogue of Latin American and Caribbean (LAC) Countries and it has become a central topic in the competitiveness agenda of multilateral organizations such as the Inter-American Development Bank, the World Bank, and the Organization of American States. During the 1990s, LAC policy makers instituted and expanded a number of $\mathrm{S} \& \mathrm{~T}$ programs aimed at supporting the effort to regain competitiveness. These programs were generally built around a demand-driven model, that is, they relied on program participants to suggest and implement projects.

Given the increasing relevance of S\&T policy for the region, the Inter-American Development Bank (IDB) undertook an evaluation of the impact of a sample of IDB's Science and Technology Programs in order to assess the impact of the two policy instruments most frequently financed by the IDB: i) Competitive Research Grants (CRG) for financing basic research activities, which are usually carried out by academic institutions; and ii) Technology Development Funds (TDF), targeted towards innovation activities in the productive sector. ${ }^{1}$ This paper summarizes the findings from the evaluation of the second policy instrument (TDF), covering the evaluations of TDF in four Latin American countries: Argentina, Brazil, Chile and Panama. ${ }^{2}$

All these evaluations were done at the recipient level using data drawn from innovation and industrial surveys combined with the administrative records of the units that administer the TDF. Given the absence of randomized experiments, the studies estimated the impact of the TDF using quasi-experimental techniques applied to comparable participating and non-participating firms in order to minimize the effects of any selection bias. Four levels of potential impact were considered: R\&D input additionality, behavioural additionality, increases in innovative output, and improvements in performance.

In terms of input additionality, the evidence suggests that TDF do not crowd out private $R \& D$ investment and that they positively affect $R \& D$ intensity. In two cases (Argentina

\footnotetext{
\# UC Berkeley and University of Maastricht, e-mail: bhhall@econ.berkeley.edu

* Inter-American Development Bank - Office of Evaluation and Oversight \& University of Insubria, email: alessandrom@iadb.org

${ }^{1}$ This evaluation was conducted by the Office of Evaluation and Oversight (OVE) during the 2005 ex post evaluation cycle.

${ }^{2}$ For detail on the individual studies see: Benavente et al. (2007), Binelli and Maffioli (2006), Chudnovsky et al. (2006), De Negri et al. (2006a and 2006b) and IDB (2007). Preliminary results on a TDF in Colombia are also available in OCyT (2007).
} 
and Brazil), the TDF even produce multiplier effects on R\&D. The results also suggest that different financing mechanisms have differential impacts on firms, with low cost credit for $\mathrm{R} \& \mathrm{D}$ projects having a clearer positive impact than matching grants. However, the studies also found that for some groups of beneficiaries - notably new innovators matching grants seem to be more effective.

Behavioral additionality is defined as changes in firm innovation strategy induced by the TDF. The empirical results suggest that the participation in TDF does produce a more proactive attitude of beneficiary firms towards innovation activities. Although in this case data are available only for Chile and Panama, the evidence suggests that the TDF positively affect a firm's willingness or capability of interacting with external sources of knowledge and financing, which are proxies for changes in the firms' innovation strategy.

In terms of innovative output, the results are more disappointing. In almost all the cases the analyses did not find statistically significant impacts on conventional measures of innovative output, such as patent grants and new product sales, although it is possible that not enough time had elapsed between the subsidy to observe its full effects. The results are more encouraging when patent applications are considered, although only the Brazilian FNDCT evaluation had such data available to it.

In terms of firm performance the evidence is mixed. There are positive impacts on firm growth, but there are no corresponding positive impacts on measures of firm productivity. However, there are two reasons to expect fairly weak results in the case of innovative output and performance: first, the impacts have been measured over a fairly short time period. Second, as we show in the next section, if the TDF are working correctly, the rate of return to innovation for firms receiving subsidies should fall, which implies that the direct and immediate effects may be rather small.

Although this review has to be considered as a first step in a wider and more intense effort of understanding the effectiveness of the TDF, the results do suggest the need for a more accurate targeting of this instrument. The TDF design and implementation have to be based on a more tailored assessment of the country specific market failures and of firms' constraints. In addition, the qualitative evidence suggests that financial support should be complemented with technological services and infrastructure, such as those provided by universities and research centers.

This paper is structured into six sections. After this brief introduction, section 2 presents the rationale for promoting innovation through $R \& D$ subsidies and discusses the impacts we might expect to find. Section 3 provides a review of the recent evolution of S\&T sector and policy framework in LAC and the role of the IDB in this framework. Section 4 summarizes the evaluative framework, presenting the questions of interest, the indicators and data sources and the methodological approach followed. Finally, section 5 presents the empirical results and section 6 gives some concluding remarks.

\section{The Rationale for Promoting Innovation through R\&D Subsidies}

The prime justification for promoting firm investments in R\&D through public financing is related to the need to correct market failures in innovative effort arising from financial 
constraints and the lack of appropriability. ${ }^{3}$ In addition, evolutionary scholars argue that public intervention is also justified by the need to address issues related to the dynamic, collective and uncertain nature of the innovation process, such as the linkages among and absorptive capacity of the agents of the National Innovation System (NIS).

A financially constrained firm cannot undertake certain potentially profitable innovation projects because asymmetric information and moral hazard problems increase the cost of credit, making some marginal projects infeasible or unattractive (Hall 2002). Even for firms that are not financially constrained, financing aid could reduce the financial risk of innovation to the firm via cost-sharing.

Although the provision of subsidized financial resources can generally help firms to overcome financial constraints, the effectiveness of this policy may be limited by the presence of rent seekers. When a firm's preferences are not observable, the provision of subsidized financial resources will incur the risk of attracting and financing firms that have already reached their desired level of $R \& D$ investment and seek low-cost public resources for other types of investments. ${ }^{4}$ In this case, the potential positive effect of the public financing is undone by an internal transfer of resources, displacing private funds for other investments and no increase in R\&D spending is observed. As Wallsten (2000) states, if R\&D investment has short-run diminishing returns and the firm has an equilibrium level of $R \& D$ investment funded with its own funds, public funding will cause the firm to reduce its own expenditure by the whole amount of the subsidy and its total R\&D investment would remain unchanged.

A number of policy instruments are commonly used to address appropriability problems and financial constraints in innovation. These include public subsidies (grants and matching grants), targeted credit, tax incentives, and the intellectual property system. The first two (grants and credit) are the instruments reviewed in this paper. In both cases they are targeted towards $\mathrm{R} \& \mathrm{D}$ investment in the countries considered. It is useful to review the implications of economic theory for the behavior of firms receiving these two different types of subsidies. The first and most important result is that because the subsidies are designed to reduce the cost of $\mathrm{R} \& \mathrm{D}$ capital, the marginal rate of return to $\mathrm{R} \& \mathrm{D}$ in the firms receiving them should fall, not rise. This counterintuitive result is important to keep in mind when looking at the performance results of the subsidies.

The two different types of subsidy will also have different effects that depend on the financial position of the firms receiving them. To see this, assume that each firm faces a downward sloping demand for $R \& D$ and a supply cost of $R \& D$ capital that is flat until internal funds for R\&D investment are exhausted, then jumps up to the cost of external funds, increasing as more and more external funds are needed. Absent the subsidies, each firm does R\&D at the level where the demand and supply curves intersect. This situation is shown in Figures 1a and 1b: the curve labeled $S$ is the supply of funds and D1 through D4 represent the demand for funds by firms with various levels of financial constraint.

\footnotetext{
${ }^{3}$ As first described by Nelson (1959) and Arrow (1962), to the extent that knowledge cannot be kept secret, the returns from investing in the production of science and technology cannot be fully appropriated by the investor; the private returns associated with an investment in S\&T are therefore much lower than the social ones.

${ }^{4}$ On the so-called crowding out effect see David et al. 2000, Klette et al. 2000 and Chudnovsky et al. 2006.
} 
The curve $S^{\prime}$ in Figure 1a illustrates the effect of a (project neutral) matching grant that lowers the cost of financing below the cost of internal funds for R\&D spending up to the amount of the grant and increases the point at which internal funds are exhausted by the amount of the matching grant. ${ }^{5}$ In the example shown, the agency matches the recipient spending one for one, the cost to the recipient of each additional currency unit spent on the project will be halved. The effect will vary for the four different types of firms: firm 1 was not doing R\&D before, and the matching grant will induce it to undertake R\&D. Firm 2 will substitute the funds from the matching grant for its own and will not increase its spending on $\mathrm{R} \& \mathrm{D}$, which is sometimes considered rent-seeking behavior, although it does not really generate any deadweight loss, given the costs of capital and the rates of return. Firm 3 (slightly financially constrained) will probably find that its cost of capital has dropped significantly on the margin and therefore ought to increase its investment significantly. On the other hand, firm 4 (very financially constrained), will see a smaller fall in the cost of capital and will therefore increase its R\&D only slightly.

\section{[Figure la about here]}

The picture for credit subsidies is slightly more complex, depending on whether the subsidies lower the cost of capital below the cost of internal funds or not. If not, then firms 1 and 2 will not change their behavior, nor will they apply for funds. Firm 3 will increase its $R \& D$ slightly and firm 4 will increase its R\&D more (because the decline in capital cost will be greater). On the other hand, as illustrated by $S^{\prime}$ in Figure $1 \mathrm{~b}$, if the new cost of capital lies below the cost of internal funds up to some spending limit, firm 2 will see crowding out and the result will be similar to the case of matching grants. For firms 3 and 4, the result is similar to the case where the cost of capital with the credit subsidy is above the cost of internal funds.

\section{[Figure 1b about here]}

The conclusion is that crowding out is a possibility for firms that rely on internal funds for investment, but unlikely for those that are financially constrained. Although in the latter case, they can always divert funds to other (non-R\&D) projects, given the lowered cost of capital, it would probably not be rational to do so. A second conclusion is that matching grants are likely to have more impact on firms that are only slightly constrained, because they simply remove the constraint, whereas credit subsidies are effective over a wider range of financially constrained firms, depending on the size of the loans for which they are available. Finally, in all cases, the observed rate of return to $\mathrm{R} \& \mathrm{D}$ is expected to stay the same or to fall.

There are several caveats to this analysis. First, it has assumed that both the grants and the credit are completely project-neutral, in the sense that they are not chosen to favor those with a high social rate of return or a high gap between the social and private rates. It has also assumed that the firms are free to spend the funds in any way they wish, once they have received them. If socially beneficial projects are to be favored in the selection process, it will also be necessary to monitor the firm's activities carefully, as the

\footnotetext{
${ }^{5}$ This analysis assumes that the R\&D project is a relatively small fraction of the firm's R\&D spending. In the case where the firm does little $R \& D$ other than that associated with the project, the effect of the grant will be to induce the firm to undertake R\&D.
} 
incentives to shift the funds to other activities are greater in the case where the opportunity cost of funds exceeds the private returns from a particular project.

Finally, the analysis above is essentially static and ignores learning and other dynamics. One important effect of these instruments is to ease the firm's transition into a more innovative state, at which point its own R\&D demand curve may shift out, and the supply curve of funds may also shift out, due to increased internal funds and greater familiarity with and reputation in the financial markets. These effects could be important, but are not easily captured by the short period of data available in these evaluations.

\section{S\&T Sector and Innovation Policy in Latin America and Caribbean}

This section briefly assesses the recent evolution of S\&T sector and policy framework in LAC. The discussion focuses, in particular, on the specific constraints that affect the region's performance in comparison to other geographical areas, and on the policies put in place by the LAC governments in order to respond to these challenges. Much of the evolution of S\&T policy in the region has developed in tandem with shifts in the policy focus and strategy of the IDB, as will become clear.

Recent evidence suggests that the S\&T sector in Latin America has been progressing in absolute terms but falling behind in relative terms. ${ }^{6}$ This statement certainly holds when input variables such as R\&D investment levels are observed: according to the UNESCO science report in 2005 (UNESCO 2005), LAC economies account for just a small fraction of the world expenditure in R\&D and this share has even contracted between 1997 and 2003 (from $3.1 \%$ to $2.6 \%$ ). Overall investment in R\&D has always been low in the LAC region and it has not significantly improved over time. Between 1991 and 2003, the R\&D investment rate increased only slightly (from $0.49 \%$ to $0.57 \%$ of GDP). Consequently, not only has the gap with highly developed economies not narrowed, ${ }^{7}$ but the region has also fallen behind other emerging areas such as East Asia and Eastern Europe, where in 2003 the R\&D/GDP ratio reached $1.2 \%$ and $0.97 \%$ respectively.

In particular, the LAC economies have historically experienced a low participation of the productive sector in $R \& D$ investment. The limited innovative effort of firms has become more of a concern as many of the regional economies have shifted their development strategy from the traditional "import-substitution industrialization" (ISI) to an openmarket approach at the beginning of the 1990s. Although the LAC governments expected an overall net benefit from opening up their economies, they also acknowledged that the potential cost of adjustment depended on the firms' capability to adapt to a completely new business environment.

Why do the LAC economies and, in particular, LAC firms tend to under-invest in R\&D? Recent studies clearly rule out the argument that low R\&D expenditures and limited participation of the productive sector in innovation activities are the consequence of low rates of return to these kinds of investments (Lederman and Maloney 2003, De Ferranti 2003, and Benavente et al. 2005). Lederman and Maloney (2003) find rates of return to

\footnotetext{
${ }^{6}$ Many surveys on this topic have been recently produced. For a detailed discussion see, among others: IDB 2001, ECLAC 2004, Velho 2004 and Hall 2005.

${ }^{7}$ In 2003 , R\&D accounted for $2.62 \%$ and $1.7 \%$ of the GDP in the US and Europe respectively (RICYT, 2006 and UNESCO, 2005).
} 
R\&D that are higher for developing countries - principally in LAC and Asia - than for advanced countries. ${ }^{8}$ They then observe that since these returns far exceed those of physical capital, LAC economies should be investing over twice what they presently do. ${ }^{9}$ Therefore, evidence suggests that the low private R\&D investment in the LAC countries depends on other factors (Lederman and Maloney 2003 and De Ferranti 2004): (i) short planning horizons brought on by persistent macro volatility; (ii) financial constraints; (iii) weak intellectual property rights; (iv) low quality of research institutions; (v) failure to mobilize government resources for this activity; and (vi) a rentier mentality due to a long history of passive natural resource exploitation.

Lack of skilled human resources has always imposed serious constraints on LAC innovation systems. In spite of some general achievements in terms of literacy, enrollment and tertiary education, recent studies (De Ferranti et al 2003, Velho 2004, and Hall 2005) point out that the average educational attainment in many LAC Countries is still low and that education is distributed less equitably that in other emerging regions. In many LAC countries tertiary and secondary education are unbalanced, the latter being too low relative to the former, and LAC students still perform poorly in international comparison tests, especially in math. This unbalanced education system partially explains the limited Latin-American capacity of absorbing new technology. In fact, although tertiary education generates a stock of scientists and engineers in line with the income level of LAC economies, secondary education has failed to provide the workforce with up-to-date technical knowledge. To make this problem even worse, only a small share of researchers and scientists works in the productive sector (around $11 \%$ in most countries) while the majority works in public and academic sectors.

Regional performance in terms of R\&D outputs is consistent with the allocation of effort at the input level. On one hand, the region has experienced non negligible improvements in the productivity of scientists and researchers. Figure 1 in the appendix clearly shows that a partial catching up has occurred in terms of scientific production (both when publications are weighted by number of researchers and when weighted by GDP). On the other hand, the results in terms of innovative output related to the productive sector are much more disappointing: the number of patent applications filed annually by LAC residents increased very slowly between 1991 and 2005 (2.6\% per year according to RICYT 2006 data $^{10}$ ) and the gap with developed economies increased.

The World Bank's “Knowledge for Development" indicators provide further evidence of the relative decline in LAC performance. Table A1 in the appendix shows that the overall "knowledge divide" between the region and the G7 economies widened between 1995 and 2003. ${ }^{11}$ LAC is the only emerging area that experienced an increasing gap in the innovation indicator, while it has slightly improved in terms of education and information technology. Obviously enough, the cross country heterogeneity is strong: among the

\footnotetext{
${ }^{8}$ The estimated social return rate of R\&D in Latin America approaches $60 \%$ for medium income countries such as Chile and Mexico, and 100\% for relatively poor countries such as Nicaragua.

${ }^{9}$ At global interest rates of 7 percent, the number is closer to 10 times.

${ }^{10}$ Available online at http://www.ricyt.edu.ar

${ }^{11}$ Note that the change in the gap between the two periods is defined as $\Delta=\left[\mathrm{GAP}_{2003}-\mathrm{GAP}_{1995}\right]$, so that a negative sign on the change implies worsening performance on the index.
} 
upper middle income economies of the Region, only Chile reduced the gap in all the indicators, and even rose above the $\mathrm{G} 7$ benchmark in terms of economic incentive and institutional regime (EIR). Brazil was the most dynamic lower middle income country, even though its catching up process was limited by the worsening of EIR.

What has been the policy response of LAC governments? During the import substitution industrialization stage, LAC governments, supported by the IDB, attempted to expand their innovation capacity by focusing on the supply side of the research and innovation processes. Assuming a linear model of innovation from basic research to applied research to successfully commercialized new products, governments focused on the promotion of scientific research activities. According to this model, a critical mass of high quality researchers, laboratories, and universities should result in codified knowledge that can be transferred from public research organizations to the productive sector. In this context, public administrators and representatives of the scientific community decided on the allocation of public resources on the basis of national development priorities, with little or no consideration of the demand for the new technologies (Velho 2004 and ECLAC 2004). As a result, public investments were concentrated on the creation of public research infrastructure and on sectors dominated by state-owned enterprises - such as energy, telecommunications, transport and aeronautics - or those connected to public technology institutes - such as agriculture, nuclear, mining and forestry (ECLAC 2004).

At this very first stage, the organizational structure adopted by most of the LAC countries provided for the central role of research councils and national research institutes. These organizations, usually controlled by the scientific and academic community, were responsible for both the planning and implementation of the S\&T policy. ${ }^{12}$ The research itself was then performed by public research centers, universities, and national technology institutes. The absence of rigorous inter-agency coordination efforts severely limited the effectiveness of these policies and usually led to fragmentation, duplication and overlapping of initiatives (ECLAC 2004 and Velho 2004).

From the end of the 1980s, the majority of LAC governments have adopted a new approach, based on horizontal policies to be guided by the actual demand of the productive sector for innovation. The supply side approach to research funding began to be replaced by the use of market incentives and the policy focus shifted towards the needs of the productive sector. More horizontal and neutral policies towards funding have been introduced in order to let the market dictate the direction of spending. Priority has been given to instruments that foster the demand for knowledge by final users and that support the transfer of technological know-how to the production sector. The allocation of public resources shifted significantly towards instruments that supported innovation activities in response to proposals by the firms. The structure and size of financing of the scientific research sector changed dramatically: resources devoted to research infrastructure were significantly reduced in favor of those allocated to innovative activities more broadly. The remaining resources devoted to science were primarily channeled towards direct support to scientists based on quality, and, to some extent, on the promotion of linkages with the production sector.

\footnotetext{
${ }^{12}$ In cases such as the Argentinean CONICET, the council was not only responsible for the definition of political guidelines and the allocation of resources, but also directly carried out research activities.
} 
To support this new approach, governments introduced many changes to the organizational structure of the S\&T sectors. Many countries undertook a significant process of reorganization with the purpose of more efficiently dividing responsibilities and tasks among public institutions. According to the IDB (2001), the new structure should have been based on a clear separation of the political planning functions from the execution and implementation functions and, within the latter, the financing from performing activities. ${ }^{13}$ At the top of the organizational pyramid, central government agencies were empowered to articulate the S\&T policies, while the national research councils became responsible for the implementation through the coordination of the funding mechanisms. In some countries (Brazil, Costa Rica and Venezuela), this led to the creation of Ministries of Science and Technology, while in others, the policymaking authority was assigned to special divisions within other ministries. ${ }^{14}$ In yet other (smaller) countries, the national research councils, usually under the direct supervision of the presidency of the republic, have maintained their original role (Bolivia, Ecuador, Guatemala, Guyana, Honduras, Jamaica, Panama and Paraguay).

Following this change in emphasis, in the 1990s the IDB's approach to S\&T policy also shifted towards horizontal and demand driven policies, responding to the increasing LAC need to maintain or regain competitiveness in a new economic environment. Within this context, technology development funds emerged as the key instrument of the new S\&T policy. The transition from a supply side approach to a demand driven one occurred with the implementation of programs such as the Chilean Science and Technology Program (1991), and the Colombian Science and Technology Research Promotion Program (1989). Indeed, FONTEC of Chile and COLCIENCIAS of Colombia rapidly became points of reference for subsequent IDB operations. ${ }^{15}$

Although this instrument varies significantly in terms of targeting, operational mechanisms and administration rules, recent reviews identify two main technology fund systems in Latin-America (ECLAC 2004). The first system (implemented in Argentina, Brazil, Chile, Colombia, Costa Rica and Mexico) allocates resources exclusively on the basis of firm technology demand. The second system (adopted by Brazil, Chile and Colombia) requires the coordination between supply (academic institutions and research centers) and demand (enterprises). In either case, competition among project proposals from the potential beneficiaries plays a central role in determining the priorities and resource allocation of the TDF, in line with a horizontal and demand driven approach to funding.

\footnotetext{
${ }^{13}$ According to The Economic and Social Progress Report 2001 of the Inter-American Development Bank (IDB 2001), the new organizational structures should have included: "(i) a central government agency in charge of defining S\&T policy; (ii) a set of executing agencies; (iii) institutions (including public and private universities) in charge of basic and applied research; (iv) institutions responsible for defining technical norms, standards, quality control and certification; (v) institutions in charge of technical and vocational education as well as short term training of the labor force; and (vi) financial institutions and funding agencies".

${ }^{14}$ The Ministry of Planning in Colombia, the Ministry of Education in Argentina, Mexico, Peru and Uruguay, and the Ministry of Economics in Chile, El Salvador and Nicaragua.

15 The IDB projects frequently mention the FONTEC and COLCIENCIAS as benchmarks for other operations in the region (see, for example, the loan proposal of the operations in Argentina, Panama, Uruguay and Venezuela).
} 


\subsection{The design and goals of the TDF}

The TDF operated with features and modalities that varied across the countries and the region over time. A brief review of the funds supported by the IDB reveals six main features of this instrument: (i) a demand driven approach; (ii) implemented via subsidy; (iii) co-financing; (iv) evolution from neutral to targeted; (v) competitive allocation of resources; and (vi) execution by a specialized agency.

(i) Demand-driven approach: in the early 1990s IDB operations supported funds that exclusively financed projects designed and submitted by final users. Therefore, the beneficiary demand determined the policy priorities and the resource allocation. More recent IDB operations slightly reduced this emphasis on the demand by also financing service providers, such as technology service centers.

(ii) Subsidies: grants and matching-grants have become the common financing method of the IDB funds, while over time the Bank has abandoned other means of subsidizing innovation projects, such as conditional credit lines. ${ }^{16}$

(iii) Co-financing: the funds never cover all costs of the financed projects. They always require the beneficiaries to participate in the financing of the initiative, usually on an equal cost-sharing basis.

(iv) Evolution from neutral to targeted: although in the early 1990s IDB funds were designed on a principle of non-discrimination, later on the funds adopted more targeted approaches. Different justifications supported the initial preference for neutrality. From the free market perspective, neutrality aimed at not interfering with the market resource allocation. In a more evolutionary perspective, the initial neutrality aimed at facilitating a policy adjustment process. In the first phase, the governments needed to identify the industryspecific externalities and market failures. This exploratory neutral approach was intended to allow developing more targeted policies in a second stage. Further, in the early stages the massive and flexible support to innovation activities aimed at facilitating the "endogenization and routinization" of R\&D in the productive sector (Teubal 1996, 1998, 2002).

(v) Competition in the allocation of resources: the early 1990s IDB funds operated on the basis of an "open-window" mechanism, where firms could apply at any time and were not competing directly with other firms for funds, except to the extent that earlier applications were more likely to be funded. Later the funds adopted competitive mechanisms such as calls for innovation project proposals.

(vi) Execution by a specialized public agency: although the institutional setting for the funds' execution differs on a across countries and operations basis, many funds are operated by an independent specialized organization. Over time, this tendency has generated some concerns about the coordination between different agencies and the definition of roles within the sector.

\footnotetext{
${ }^{16}$ In this method, loans could be partially or even totally forgiven on the basis of three criteria: the success or failure of the project; the nature of the beneficiary; and, the level of the project technological risk.
} 
Table 1 summarizes the TDF studied in this evaluation. It is worth noticing that the FNDCT is the only TDF evaluated that exclusively promotes partnership between firms and research institutions (i.e. universities and research centers).

\section{[Table 1 about here]}

Because they are neutral with respect to the projects that can be proposed, TDF mainly address market failures related to financial constraints and only incidentally those related specifically to lack of appropriability, although project selection does take account of social returns in some cases. To tackle asymmetric information and adverse selection problems, the TDF institutional setting usually includes a public agency responsible for selecting the innovation projects from among the proposals submitted. The role of this agency is at least three-fold: first, the agency acts as a screener, conveying the technical knowledge that the financial markets lack or are not willing to develop. This process should reduce the usual asymmetry of information between the financial sector and the innovative firms. Second, the agency has the possibility and the authority of monitoring and supervising the firm investment. This function could diminish the risk of financing firms that seek to divert resources to other uses. Third, the agency tries to select those projects have the highest social returns, conditional on being profitable for the firm. Under these assumptions, the agency selects projects that are unlikely to be financed otherwise. In extreme cases, the funds may finance projects directed toward the creation of public research goods, ensuring that firms undertake projects with very high social returns but low private appropriability. Thus the two policy goals, mitigating financial constraints and supporting investments with a large gap between private and social returns, are to some extent blended.

The presence of the specialized agency marks one of the most important differences between TDF and fiscal tax incentives. In the latter case, the firms receive the public financing in the form of tax credits or deductions calculated on predefined accounting categories. Governments usually adopt these kinds of incentives because they are available to all qualifying firms automatically and therefore minimize public interference with firm decisions. Indeed, tax incentives do not imply any quality assessment of the firm's R\&D expenditure, nor distinguish sectors or specific areas of financing, although they may be targeted towards growing or smaller firms in some cases. In addition, automatic incentives avoid incurring the costs of establishing an S\&T agency, which can be high when a country lacks the technical expertise for innovation project assessment. ${ }^{17}$

Over time the TDF in the LAC region have adopted matching grants as the most common method of financing, abandoning the use of credit lines. ${ }^{18}$ The advantage of matching grants over credit is that they reduce administrative costs, because they do not require the collection of repayments. In addition, matching grants do not require collateral, making this option particularly well suited for SMEs and new firms. The disadvantages of matching grants relative to credit are the following: i) the financial resources expended

\footnotetext{
${ }^{17}$ On the other hand, it has to be kept in mind that such incentives will require auditing expertise in the tax authority that is knowledgeable about the components of R\&D spending.

18 Another alternative could be public procurement (public contracts). This instrument produces more or less the same effect of a subsidy but it has the additional advantage of signaling the market that the innovation projects undertaken by the firm do have a market.
} 
are not recovered, at least in the short to medium run; ${ }^{19}$ ii) grants do not help the firm build up a credit reputation in the financial markets; and iii) because they do not need to be paid back, matching grants potentially attract more rent seeking firms and therefore increase the risk of crowding out own R\&D.

Some TDF include specific lines of financing designed to promote linkages between research institutions and firms. In this case the goal of the TDF is not only to subsidize the cost of the project, but also to reduce the technical risk as perceived by the firm. In fact, there are situations where a firm could decide not to undertake a project even when not financially constrained because the project requires it to invest in some technical capability or infrastructure that has the nature of a public or semi-public good (such as highly specialized laboratory and equipment). Firms may also have the potential to discover new investment opportunities from the interaction with scientific institutes and research centers, but find the cost of exploring this option too high. In this case, public financing seeks to make research infrastructure available to firms and to reduce the costs of accessing highly specialized researchers.

Other specific TDF promote joint ventures and alliances for the performance of innovation and research projects. In this case, the rationale for intervention is threefold: first, the TDF take advantage of potential economies of scale and scope of the research activities. Second, they reduce the problem of private $R \& D$ investment duplication (Martin and Scott 2000). Although cooperation can degenerate into collusion, it can also significantly mitigate the negative effects of both free-riding and duplication of research effort. To deal with this trade-off, public programs usually promote firms' cooperation in the first stages of R\&D activities and foster competition in a second stage (Martin and Scott 2000). ${ }^{20}$ Third, the promotion of firm-level research agreements aims at fostering interactive learning processes. The interaction with other firms allows a firm to expand its knowledge base beyond its own endowment. In this case systemic failures due to coordination costs and limited absorptive capacity justify the public financing of firms' networking activities (Maffioli 2005).

\subsection{Other innovation policy interventions}

Only a few of the LAC economies (Argentina, Colombia, Brazil and Mexico) have adopted fiscal incentives for technological innovation. These incentives usually include: (i) reduction in the corporate income tax; (ii) reduction in the value-added tax; (iii) accelerated depreciation of capital goods and equipment acquired in the context of an innovation project and (iv) fiscal credit for expenses in R\&D. According to Hall (2005), the scarce utilization of this policy can be ascribed to some specific features of both the instrument and the Latin American context. First, fiscal incentives tend to be expensive in terms of foregone tax revenue unless they are incremental, and an incremental fiscal credit is very complex to design and administer. Second, to be effective they require sufficient corporate tax bills and an efficient tax enforcement system.

\footnotetext{
${ }^{19}$ In the long run and if the project financed by TDF is successful, the public financial resources should be recovered through higher income from corporate taxes.

${ }^{20}$ For example, in the United States, the National Cooperative Research Act of 1984 explicitly exempted R\&D cooperatives and Research Joint Ventures (RJVs) from antitrust enforcement.
} 
The LAC governments' attitude towards the strengthening of the intellectual property rights (IPR) systems, as required by the TRIPS agreement, has been much more controversial. This is probably due to the very nature of this institution. Although the importance of the IPR system is widely acknowledged, scholars and policy makers are still debating how strong the system should be and how it should evolve in developing countries. Advocating stronger intellectual property rights presumes that the combined positive impact of the appropriability incentive for the innovator and the disclosure element for peers (resulting in greater innovation) outweighs the negative impact of temporary market distortions (resulting in higher prices for consumers and slower technology diffusion for producers) and the decreased opportunities for learning via imitation. Therefore, timing becomes the key factor for the IPR policy: protecting IPR very early in the technological catch-up process can discourage an important channel for technological learning. Failing to protect IPR when private firms are launching R\&D programs could weaken the incentives to innovate. This only partially explains why LAC economies have not yet developed IPR system in line with the TRIPS agreement. Some institutional weaknesses could have contributed to this situation as well. Indeed, efficient IPR systems require strong institutional capacity and credible enforcement.

In addition to fiscal measures and IPR reforms, LAC governments have also implemented some complementary instruments to strengthen S\&T policy. For example, Brazil has used governmental procurement to support the national software industries. Chile and Brazil have also introduced some pilot programs to promote venture capital for innovation projects. Many countries (Brazil, Chile, Mexico, Nicaragua) have implemented networking and clusters policies to support the technological upgrade of small and medium-sized enterprises (SMEs). Chile, Costa Rica and Mexico have implemented instruments aimed at attracting Multinational Enterprises (MNEs) and at promoting linkages with local suppliers.

\section{Evaluation Strategy, Data Source, and Methodology}

The TDF impact evaluation strategy is inspired by the linear (sequential) models of innovation suggested by Pakes and Griliches (1984) and Crepón et al. (1998), which describe the relationship between firms' investment in R\&D, innovation output, and productivity change. Although the linear model is often critiqued because it omits feedback elements in the innovative process, from the perspective of a policy instrument like R\&D subsidies, the first order impact will be well-captured by this model. In any case, the goal of the evaluation was not to estimate the complete model, but to use it as a guide to the causality chain that leads from the provision of the subsidy to the R\&D investment to the innovative outputs and then finally to the performance outcomes.

Figure 2 summarizes the temporal sequence of events that are involved in the assessment of the impact of the TDF. Table 2 summarizes the indicators (both objective and subjective) used for evaluation and the sources for the data used for each of them. Note that the degree of availability of these indicators varies across programs and countries.

\section{[Figure 2 about here]}

\section{[Table 2 about here]}

Before describing the four evaluations in detail, we briefly address the issue of how to measure innovation activities and research productivity. Objective criteria of 
innovativeness are the introduction of "new to the market" innovations in certain industries (proxied by patents or new product sales) or the quantitative efforts of firms in developing innovations (proxied by $\mathrm{R} \& \mathrm{D}$ expenditures). Considering the limitations of these indicators in an economic context largely based on small firms, these criteria may underestimate the innovativeness of firms and could lead to a misleading perception of the innovation process.

On the other hand, subjective criteria are based on largely on the judgment of participants and therefore reflect a more personal perception of innovation capabilities. Such criteria usually rely on qualitative information collected via direct surveys. Interviewees are asked to provide information regarding particular events such as the introduction of innovations in the firm, which are not based on quantitative, measurable information but on the interviewees' perception of the issue. ${ }^{21}$ Nevertheless, despite this bias, subjective criteria may provide a valuable source of in-depth information on firms' innovation activities, especially in some contexts in which the overview of R\&D efforts and patent activities do not provide a complete view of the innovation phenomenon. ${ }^{22}$ For this purpose many efforts have been devoted to standardizing the collection of information about innovation in firms that is based on both objective and subjective criteria. The most successful effort is the methodology proposed and adopted by the OECD. ${ }^{23}$

Given the pros and cons of both subjective and objective measures, the evaluations looked at four different levels of impact, involving both types of indicators wherever possible. The first level was simply firm expenditures on $R \& D$, in order to determine whether they are complements or substitutes for the R\&D subsidies, that is, whether the subsidy increases the firm's own spending on R\&D.

The second and third levels of evaluation look at the impact of the subsidy on firm behavior and innovative output. As is often pointed out by innovation scholars, when the impact of S\&T policy is formulated simply in terms of input and output measures, the firm is largely treated as a black box and the long run impacts on its own capabilities or organization are ignored (OECD 2005). As a partial corrective to this approach, two of the evaluations (those for FONTEC in Chile and FOMOTEC in Panama) complement the input level analysis with a limited analysis of the TDF impact on firm behaviour. In particular, the evaluation looks at (i) process innovation and organizational changes and (ii) access to external knowledge resources.

The innovative output indicators usually employed in the literature are patents, sales of new products and the introduction of a new or improved product or process. The studies we review use all indicators where they are available (new product information in three

\footnotetext{
${ }^{21}$ For instance, subjective criteria may refer to the provision of information on the introduction by firms of products and processes substantially different from the previously adopted or the introduction of industry specific innovations, which are otherwise difficult to identify. This does not imply that the invention of products/processes can be considered innovative for the whole industry, but evidences some incremental efforts of the firm in improving competitiveness.

${ }^{22}$ This is especially true for industries in which patent activity is low or for SMEs, in which R\&D activity is normally not formalized.

${ }^{23}$ In 2000 this methodology was adapted to the LAC context by a group of scholars and experts, producing the Bogotá Manual.
} 
cases and patents in three cases), although patents have limitations as a measure of innovative output in developing countries.

The final level of impact evaluation was firm performance, measured as growth or changes in sales, employment, exports, and productivity. Unfortunately, the time period available for the evaluations was rather short for full impacts on these variables to be felt.

Each evaluation we review in this paper is based on a unique dataset where both primary sources of information, such as the surveys collected in Chile and Panama, and secondary sources of information, such as the innovation and industrial surveys used in Argentina and Brazil, were merged with the administrative records of the program executing unit. This procedure allowed to exactly identify the specific firms that participated in the evaluated programs. In addition, in all the cases the control group was constructed using a sample of firms that did not receive any other comparable treatment, in order to maximize the accuracy of the impact estimation. ${ }^{24}$

\subsection{Evaluation Methodology}

To measure the impact of TDF on outcome indicators, each individual program-level evaluation followed the basic government program evaluation techniques developed in the econometrics literature. To the best possible extent, each program has to be analyzed using a counterfactual perspective in order to reduce potential selection bias. These techniques provide for a rigorous strategy for identifying a statistically robust control group of non-beneficiaries, and following both the "treated" and the control group over time. The ideal evaluation design is the one that creates a valid comparison group by randomly allocating treatment prior to the beginning of the program, which more closely guarantees that on average the characteristics of both groups are the same.

The measurement of programs' effectiveness poses the well-known "evaluation problem". Define $Y_{i t}^{T}$ the average expenses in innovation by firm $i$ in year $t$ if the firm participates in the TDF and $Y_{i t}^{C}$ the average expenses by the same firm if it does not participate to the program. Measuring the program impact requires a measurement of the difference $Y_{i t}^{T}-Y_{i t}^{C}$, which is the effect of having participated in the program for firm $i$. Computing $Y_{i t}^{T}-Y_{i t}^{C}$ requires knowledge of the counterfactual outcome $Y_{i t}^{C}$ that is not empirically observable since a firm can not be observed simultaneously as a participant and as a non-participant. The evaluation will not be able to compute the program impact for an individual firm but we can evaluate an average effect of program participation, $E\left[Y_{i t}^{T}-Y_{i t}^{C}\right]$, by comparing data on participating and non-participating firms.

Defining $D_{i}$ as the dummy variable for program participation, the average treatment effect of the program will be given by:

$$
\Delta=E\left[Y_{i t}^{T} \mid D_{i}=1\right]-E\left[Y_{i t}^{C} \mid D_{i}=0\right]
$$

\footnotetext{
${ }^{24}$ In most of the cases the evaluated programs were the only national sources of financing specifically devoted to innovation projects.
} 
Subtracting and adding $E\left[Y_{i t}^{C} \mid D_{i}=1\right]$, we obtain:

$$
\begin{aligned}
& \Delta=E\left[Y_{i t}^{T} \mid D_{i}=1\right]-E\left[Y_{i t}^{C} \mid D_{i}=0\right]-E\left[Y_{i t}^{C} \mid D_{i}=1\right]+E\left[Y_{i t}^{C} \mid D_{i}=1\right] \\
& =E\left[Y_{i t}^{T}-Y_{i t}^{C} \mid D_{i}=1\right]-E\left[Y_{i t}^{C} \mid D_{i}=0\right]+E\left[Y_{i t}^{C} \mid D_{i}=1\right]
\end{aligned}
$$

The term $E\left[Y_{i t}^{T}-Y_{i t}^{C} \mid D_{i}=1\right]$ in (2) is the average effect of the treatment on the treated that we try to isolate. The difference $E\left[Y_{i t}^{C} \mid D_{i}=1\right]-E\left[Y_{i t}^{C} \mid D_{i}=0\right]$ is the selection bias: besides the effect of the program there may be systematic differences between participating and non-participating firms that affect the program's impact.

A simple estimator of $\Delta$ using the sample analogue $E\left[Y_{i t}^{T} \mid D_{i}=1\right]-E\left[Y_{i t}^{C} \mid D_{i}=0\right]$ will give an unbiased estimate of the program impact only if there is no selection bias, that is only if $E\left[Y_{i t}^{C} \mid D_{i}=1\right]-E\left[Y_{i t}^{C} \mid D_{i}=0\right]=0$. However, participating and non-participating firms differ in a number of dimensions (e.g. size) that are likely to affect both the level of innovation expenditures and the probability of getting financed through the TDF. Therefore, the simple difference in mean outcomes between participants and nonparticipants is capturing the effect of program participation together with the impact of third factors affecting both the decision to invest in innovative activities and to participate in the program.

The TDF evaluations follow quasi-experimental designs in all the cases, given that a truly randomized design was not implemented for any of the projects reviewed. All the evaluations tried to identify comparable treated and non-treated individuals in order to minimize the effect of potential "selection biases" on the evaluation results. A control group was identified using a number of different methods: propensity score matching procedures, difference in differences estimation, fixed effect panel estimation, and instrumental variable estimation. ${ }^{25}$

\section{Empirical Results}

This section reports the results of the four levels of the TDF impact evaluation: the TDF impact on R\&D investment (input additionality); the impact on firm's innovative behavior (behavioral additionality); the impact on patents and innovation outputs (innovative output); and the program impact on sales, employment, productivity and exports (firm performance). A detailed summary of results and methodologies is given in an appendix Table A2. Unfortunately, the heterogeneity of available information and data sources did not allow the studies reviewed here to adopt absolutely identical estimation techniques for all impact evaluations. As a consequence, results are sometimes not fully comparable, and in some cases not even available, for all countries. Nevertheless, they

\footnotetext{
${ }^{25}$ On these techniques, see among the others: Heckman et al. (2000), Blundell and Costa-Dias (2002), Jaffe (2002), Smith and Todd (2003).
} 
offer an unprecedented opportunity to evaluate the effectiveness of an important component of S\&T policy in the LAC region during the past 15 years.

The evidence shows that TDF do not crowd out R\&D investment; on the contrary, in many cases they significantly increase firms' investment in R\&D (see Table 3). Based on the arguments made earlier, this result implies that the financial constraints faced by potentially innovative firms are truly an obstacle to private investment in R\&D. In three cases where the evaluations were able to estimate the impact of the TDF on R\&D investment net of the subsidy (ADTEN, FNDCT and FONTAR-TMP I), the evidence shows that TDF have multiplier effects, where beneficiaries increase their investment in R\&D beyond the amount financed by program funds. ${ }^{26}$ Although the stylized framework we presented in the beginning rules out such effects, this result is consistent with what was expected from the development literature: by providing the opportunity to overcome liquidity and credit constraints, TDF programs should allow beneficiary firms to undertake projects at the margin of their portfolio and, eventually, to generate the technical conditions for undertaking additional innovation projects.

The clear positive impact of the FNDCT suggests that measures to encourage cooperation with public research institutes may be important, as the FNDCT is the only TDF evaluated that requires the cooperation between firms and research institutes. This particular feature of the program could have contributed to addressing both financial and technical constraints (lack of human resources, lack of own specialized research infrastructure and lack of technical knowledge, for instance).

\section{[Table 3 about here]}

Despite the limited evidence of matching-grants effectiveness, the data shows that this instrument may be effective for new innovators. In the case of the FONTAR-ANR program, although the analysis does not provide evidence of a multiplier effect at the aggregate level, the data indicates that new innovators have seen a substantial increase in their private investment in R\&D. On the other hand, the effect of matching grants is smaller for more experienced innovators, for which some evidence of displacement of resources has been found. Although some caution is called for, the result is not surprising and is consistent with the rationale that led to the implementation of the matching-grant scheme and also with the brief theoretical discussion in Section 2 of the paper. ${ }^{27}$

As opinion surveys reflect, it appears that the project beneficiaries are using TDF as a signal of firm technical capacity and ability to innovate. Qualitative information collected from the beneficiaries in both the Chilean and Argentinean cases reveals that some firms

\footnotetext{
${ }^{26}$ In the case of FONTEC, where R\&D net of subsidy was not available at the firm level, the evaluation compared the average annual impact with the average annual subsidy received by the beneficiaries, and it found that the impact is slightly lower than the subsidy. With the required caution, the evaluation concluded that some crowding out effects might have occurred, and that there was definitely no evidence of a multiplier effect. In the case of FONTAR-ANR, the evaluation found that the average effect of the program on $R \& D$ net of the subsidy was not statistically different from zero. However, the evaluation found that the program had a positive and significant effect for new innovators, that is firms that did not have investment in $\mathrm{R} \& \mathrm{D}$ before participating in the program.

${ }^{27}$ As previously pointed out, one of the main motivations for introducing the matching-grants scheme was to offer to those firms with a limited experience in R\&D activities a more accessible support than targeted credit.
} 
are using the programs as a signaling mechanism in order to obtain complementary financing from the financial sector. In particular, in the Chilean case the majority of the beneficiaries consider the public subsidy an important complementary source of financing $(50 \%)$, probably associated to a helpful signal of the quality of the project to get other sources of financing $(28 \%){ }^{28}$

Opinion surveys also suggest that human resource constraints may be mitigating TDF effects. When asked to identify the main difficulties faced during the execution of the subsidized project, the majority of the beneficiaries mentioned the lack of skilled labor force. This suggests that some sort of underestimation of the human resources required to carry out the subsidized project could have displaced other R\&D activities originally included in the firms' work plan. The fact that the participation in the program did not have an effect on physical capital investment is quite consistent with the hypothesis that the limited impact on $R \& D$ intensity is due more to a temporary adjustment in the investment decisions rather than to some sort of resource displacement.

For the Chilean and Panamanian cases the evaluation was able to look at a set of indicators of behavioural changes in firms related to innovation (Table 4). Both programs had a positive impact on variables such as the firms' ability to interact with external sources of knowledge and financing, which are proxies for significant changes in the firms' innovation strategy. A positive impact of the programs on the introduction of process and product innovations was also found. In general, the impacts were more significant in Panama than in Chile, although due to the qualitative scales employed, it is difficult to compare their magnitudes.

\section{[Table 4 about here]}

In terms of direct measures of innovative output (patents and sales of new products) the evaluation's results are more disappointing (Table 5). In almost all the cases the evaluation does not find any statistically significant positive impact. However, it is worth noting that there could be a considerable time lag between program participation and a significant change in the traditional measure of innovative output, such as patent registrations and the sales of new products. Unfortunately most of the estimates are contemporary, based on changes between the year before and the year after program participation, due to data limitations. One exception is the Brazilian FNDCT study, where it was possible to use patent applications instead of registrations. In this case, the results show a clear positive and significant impact of the program on patents applied for.

\section{[Table 5 about here]}

In terms of firm performance the evidence is mixed (Table 6). The evaluation shows mostly positive (although not always significantly so) results on sales and employment growth, but the impact on firm productivity is mostly insignificant. In general the pattern observed was one of a negative impact on productivity in the year of the reception of the funds and the year following that reception, and a positive or insignificant effect afterwards. The FONTEC, FONTAR and ADTEN and programs positively affect firms' growth in terms of employment and sales with a lag of two years, but there is no evidence

\footnotetext{
${ }^{28}$ Furthermore, thirty percent of the beneficiaries applied to the program because they believed the project would not receive any financing from the private sector.
} 
of a significant impact of the FNDCT program. In addition, only the FONTEC program seems to be effective in promoting firm exports, among those programs for which export data was available.

\section{[Table 6 about here]}

In interpreting these results, especially those in Table 6, it is appropriate to recall the analysis given earlier in the paper. Were a true random sample to be analyzed, that analysis predicted a lower rate of return to $\mathrm{R} \& \mathrm{D}$ for the firms receiving the subsidy as opposed to those that did not receive it. This may or may not translate into differences in average productivity growth of the two kinds of firms, as we would still expect that doing more R\&D would lead to higher productivity growth on average, even if the marginal return is lower. But there are good reasons to think that the average effects will be small because the marginal return is lower.

\section{Conclusions}

In this paper we have provided a meta-review of the econometric evaluation of a number of R\&D subsidy programs operated during the 1990s by Latin American governments. The main conclusions are easy to summarize: the impact of the programs on firm behavior and outcomes becomes weaker and weaker as one gets further from the immediate target of the policy instrument. There is clear evidence of a positive impact on $\mathrm{R} \& \mathrm{D}$, weaker evidence of some behavioral effects, and almost no evidence of an immediate positive impact on new product sales or patents. This perhaps to be expected, given the relatively short window over which the impacts were measured, but it might bear watching in the future.

We also found that different financing mechanisms have varying impacts on beneficiary groups. Although in general credit subsidies were more effective than grants, for new innovators matching grants seemed to be more effective, possibly because they enabled firms to overcome the fixed cost of starting up an R\&D program. Matching grants were also effective in the one program that encouraged cooperation between firms and university research centers.

The analysis and results surveyed in this paper and in the supporting material on which it is based contain several lessons for policymakers. First, the potential crowding in/out of private resources probably should be monitored carefully, in particular when nonreimbursable resources are granted. This would not necessarily imply any additional burden for the execution of the programs because the necessary data is already being collected.

There is no clear evidence that the TDF can significantly affect firms' productivity and competitiveness within a five-year period, although there is a suggestion of positive impacts. Although it is possible that TDF programs do not produce productivity and competitiveness gains, it is also possible that these impacts occur over a time frame longer that the five years for which the evaluations have data. Follow up evaluations, allowing for larger time lags to analyze the same groups of treated and non-treated firms, is probably a good idea in the case of most $\mathrm{R} \& \mathrm{D}$ public subsidies. At the same time, the goals of the various programs need to be kept in mind: if the purpose is to increase innovative activity by lowering its cost, a lower marginal private return is expected to result. 
The results here also highlight the need for other services that can complement the financial support of innovation activities. Shortage of skilled labour could significantly affect firms' innovation strategy and plans (as could have happened to some extent in Chile, for example). Government-provided access to highly educated human capital may be desirable, in particular for those firms that have limited possibility of directly hiring these specialists. The results for FNDCT in Brazil suggest that interaction between firms and universities can be an effective response to this need. 


\section{References}

Arrow, K. (1962), "Economics Welfare and the Allocation of Resources for Invention," in R. Nelson (ed.), The Rate and Direction of Inventive Activity, Princeton University Press, pp. 164-181.

Benavente H., J. M., De Gregorio J., and Nunez M., (2005), "Rates of Return and the industrial R\&D in Chile," Santiago, Chile: University of Chile and Central Bank of Chile, paper presented at the World Bank conference in Barcelona on R\&D and Innovation in the Development Process, June 9-11, 2005.

Benavente J. M., Crespi G. and Maffioli A. (2007), "Public Support to Firm Innovation: The Chilean FONTEC Experience" OVE Working Papers 0407, Inter-American Development Bank, Office of Evaluation and Oversight (OVE).

Binelli C. and Maffioli A. (2006), "A Micro-econometric Analysis of Public Support to Private R\&D in Argentina," International Review of Applied Economics, Vol. 21, No. 3, pp. 339-359.

Blundell R. and Costa-Dias, M. (2002) "Alternative Approaches to Evaluation in Empirical Microeconomics,” London: CEMMAP Working Paper CWP10/02.

Chudnovsky D., López A., Rossi M. and Ubfal D. (2006) "Evaluating A Program Of Public Funding Of Private Innovation Activities. An Econometric Study of FONTAR In Argentina" OVE Working Papers 1606, Inter-American Development Bank, Office of Evaluation and Oversight (OVE).

Crepon, B., E. Duguet, and J. Mairesse (1998) "Research, Innovation, and Productivity: An Econometric Analysis at the Firm Level," Economics of Innovation and New Technology 7(3), pp. 115-156.

David, P., Hall, B. and Toole, A. (2000) "Is Public R\&D a Complement or Substitute for Private R\&D? A Review of the Econometric Evidence," Research Policy, 29, pp. 497529.

De Ferranti, D., G. E. Perry, I. Gill, J. L. Guasch, W. F. Maloney, C. Sanchez-Paramo, and N. Schady (2003), Closing the Gap in Education and Technology, Washington, D.C.: World Bank Latin American and Caribbean Studies.

De Negri J. A., Borges Lemos M., De Negri F. (2006a) "Impact of P\&D Incentive Program on the Performance and Technological Efforts of Brazilian Industrial Firms," OVE Working Papers 1406, Inter-American Development Bank, Office of Evaluation and Oversight (OVE).

De Negri J. A., Borges Lemos M., De Negri F. (2006b) "The Impact of University Enterprise Incentive Program on The Performance and Technological Efforts of Brazilian Industrial Firms," OVE Working Papers 1306, Inter-American Development Bank, Office of Evaluation and Oversight (OVE).

ECLAC 2004, Productive Development in Open Economies, United Nations Publications, Santiago, Chile.

Hall, B. H. (2002), "The Financing of Research and Development," Oxford Review of Economic Policy, Vol. 18, No. 1, pp. 35-51. 
Hall, B. H. (2005), Government Policy for Innovation in Latin America, paper presented at the World Bank conference in Barcelona on R\&D and Innovation in the Development Process, June 9-11, 2005

Heckman, J., LaLonde, R., and Smith, J. (2000) "The Economics and Econometrics of Active Labor Market Programs," in The Handbook of Labor Economics, Volume 3A, O. Ashenfelter and D. Card (eds.), North-Holland.

IDB (2001), IPES 2001: Competitiveness: The Business of Growth, The John Hopkins University Press, Baltimore and London.

IDB (2007), "IDB's Science and Technology Programs: An Evaluation of the Technology Development Funds (TDF) and Competitive Research Grants (CRG)," OVE Evaluation Report, Inter-American Development Bank, Office of Evaluation and Oversight (OVE).

Jaffe, A. (2002) "Building Program Evaluation into the Design of Public Research Support Programs," Oxford Review of Economic Policy, Spring (18), pp. 22-34.

Klette, T., Møen, J., and Griliches, Z. (2000) "Do Subsidies to Commercial R\&D Reduce Market Failures? Micro econometric Evaluation Studies," Research Policy 29, pp. 471495.

Lederman D. and W. F. Maloney (2003), "R\&D and Development," Policy Research Working Paper 3024, World Bank, Washington.

Maffioli A., (2005) "The Formation of Network and Public Intervention: Theory and Evidence from the Chilean Experience" ISLA Working Papers 23, ISLA, Centre for research on Latin American Studies and Transition Economies, Universita' Bocconi, Milano, Italy, revised May 2005.

Martin, S. and Scott, J. (2000) "The nature of innovation market failure and the design of public support for private innovation," Research Policy 29, pp. 437-447.

Nelson, R. (1959) “The Simple Economics of Basic Scientific Research,” Journal of Political Economy 67(3), pp. 297-306.

OCyT (2007), Evaluación ex-post del Programa nacional de desarrollo científico y tecnológico. Componente de apoyo para el desarrollo tecnológico e innovación en el sector productivo, mimeo.

OECD (2005), Behavioural Additionality of R\&D Grants: Introduction and Synthesis, Working Party on Innovation and Technological Policy, Paris.

Pakes, A. and Griliches, Z. (1984), "Patents and R\&D at firm level: A first look," in $R \& D$, patents and productivity, Z. Griliches (ed.), University of Chicago Press and NBER, Chicago.

RICYT (2007), Ibero-American and Inter-American Network on Science and Technology Indicators data available at http://www.ricyt.edu.ar.

Smith, J. and Todd, P. (2003) "Does Matching Overcome Lalonde's Critique of Nonexperimental Estimators?” CIBC Working Paper Series No. 2003-5.

Teubal M. (1996), "R\&D and Technology Policy at NICs as Learning Processes," World Development, 24: 449-460 
Teubal M. (1998), Marco de Políticas para el Financiamiento de la Innovación en economías en vías de Industrialización, SDS Working Paper, Inter-American Development Bank, Sustainable Development Department.

Teubal, M. (2002) "What is the Systems Perspective to Innovation and Technology Policy (ITP) and How Can We Apply It to Developing and Newly Industrialized Economies?" Journal of Evolutionary Economics, Vol. 12, Numbers 1-2.

UNESCO (2005), UNESCO Science Report 2005, UNESCO publishing, Paris

Velho, L (2004), Science and Technology in Latin America and the Caribbean: An overview, INTECH Discussion Paper Series, United Nations University, Maastricht

Wallsten, S. (2000) "The effects of government-industry R\&D programs on private R\&D: The case of the Small Business Innovation Research Program," RAND Journal of Economics, vol. 31, pp. 82-100. 
Figure 1a: The supply and demand for $R \& D$ funds with a matching grant

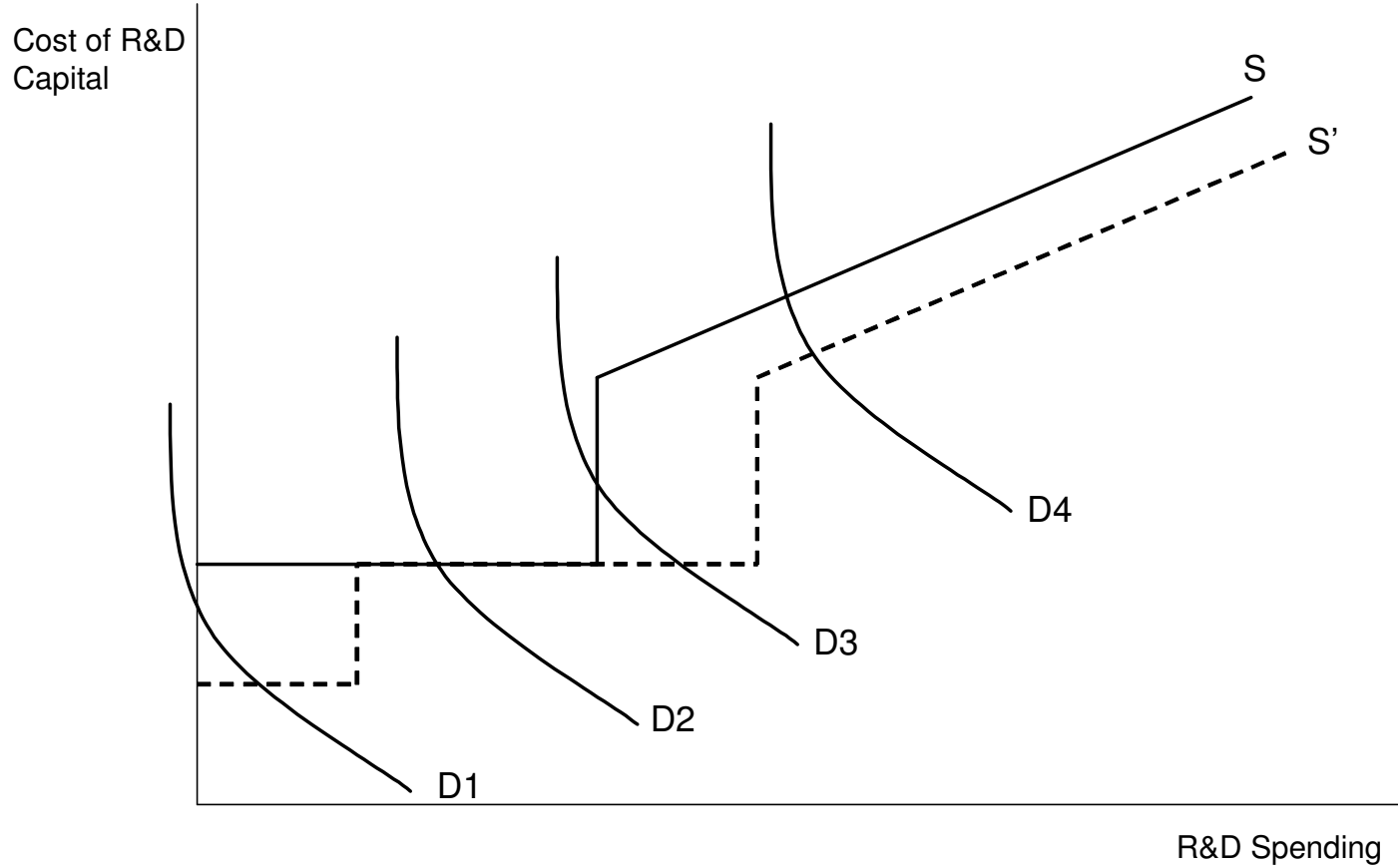

Figure 1b: The supply and demand for $R \& D$ funds with a credit subsidy

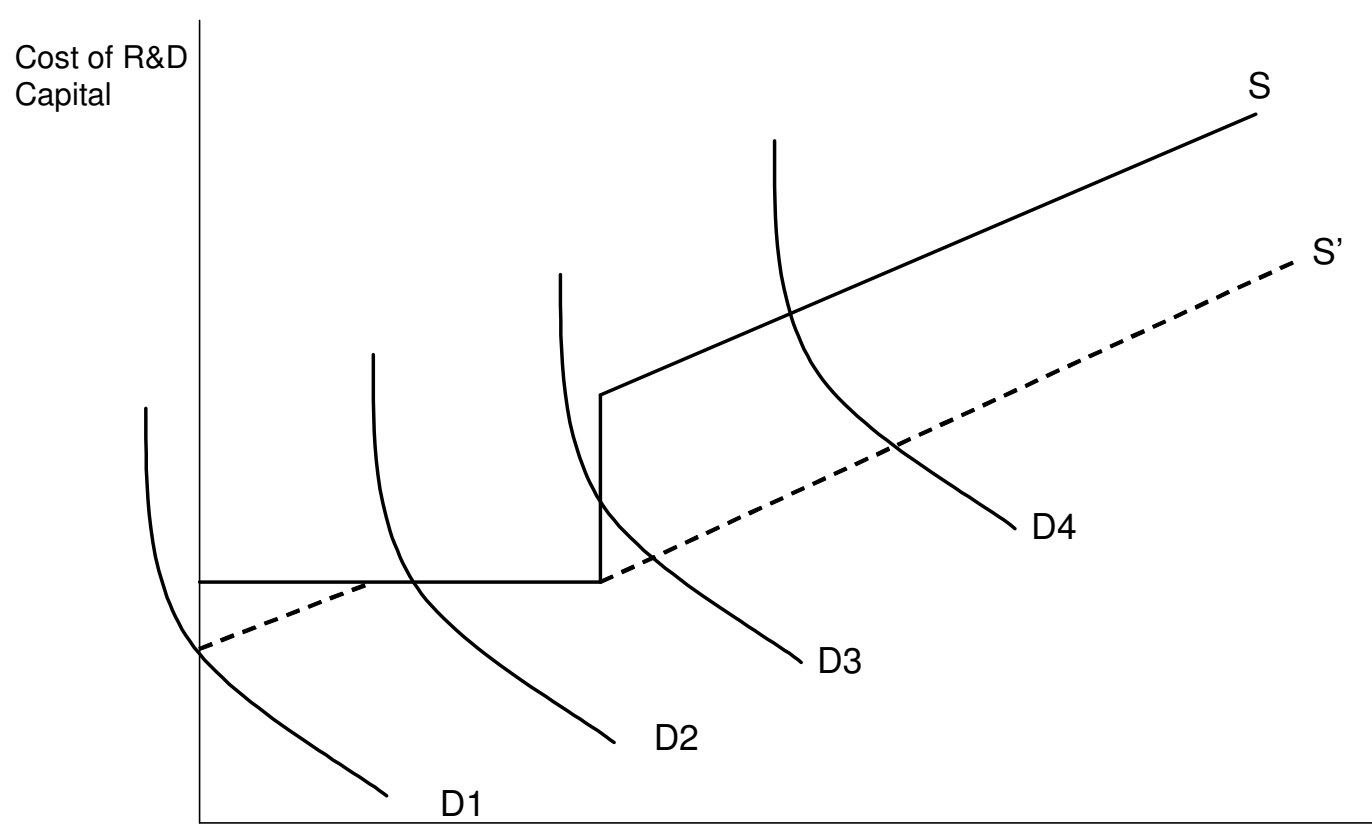

R\&D Spending

Source: authors' elaborations 
Figure 2: The evaluation model

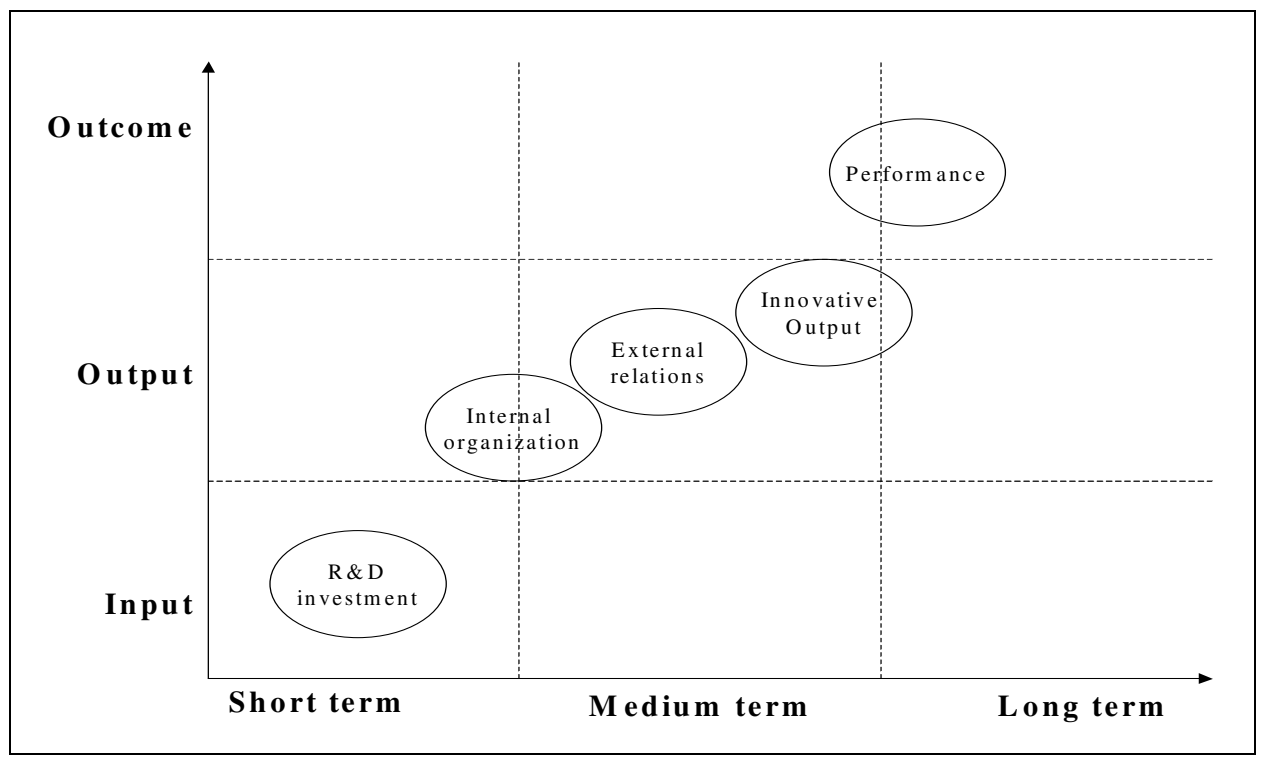

Source: Authors' elaboration 
Table 1: Technology Development Funds Evaluated

\begin{tabular}{|c|c|c|c|c|}
\hline $\begin{array}{l}\text { Country and } \\
\text { period }\end{array}$ & Name & Tools & Mechanism & Beneficiaries \\
\hline $\begin{array}{l}\text { Argentina (AR) } \\
\text { 1994-2001 }\end{array}$ & FONTAR-TMP I & Targeted Credit & Open Window & Firms \\
\hline $\begin{array}{l}\text { Argentina (AR) } \\
\text { 2001-2004 }\end{array}$ & FONTAR ANR & Matching Grants & Call for Proposals & Firms \\
\hline $\begin{array}{l}\text { Brazil (BR) } \\
\text { 1996-2003 }\end{array}$ & ADTEN & Targeted Credit & Open Window & Firms \\
\hline $\begin{array}{l}\text { Brazil (BR) } \\
\text { 1999-2003 }\end{array}$ & FNDCT & Matching Grants & $\begin{array}{l}\text { Open Window / Call } \\
\text { for proposals }\end{array}$ & $\begin{array}{l}\text { Firms and } \\
\text { Research centers }\end{array}$ \\
\hline $\begin{array}{l}\text { Chile }(\mathrm{CH}) \\
1998-2002\end{array}$ & FONTEC -Line 1 & Matching Grants & Open Window & Firms \\
\hline $\begin{array}{l}\text { Panama (PN) } \\
2000-2003\end{array}$ & FOMOTEC & Matching Grants & Open Window & Firms \\
\hline
\end{tabular}

Source: Authors' elaboration

Table 2 - Indicators and Data Sources for TDF Impact Evaluation

\begin{tabular}{|c|c|c|c|c|}
\hline & Evaluation Questions & Indicator (type) & Sources & Horizon \\
\hline $\begin{array}{l}\text { Input } \\
\text { additionality }\end{array}$ & $\begin{array}{l}\text { Does public financing crowd out private } \\
\text { resources? The evaluation looks at the } \\
\text { impact of the TDF on the beneficiaries' own } \\
\text { financial resources devoted to R\&D and } \\
\text { innovation activities, as a test for the } \\
\text { potential crowding out effect of the public } \\
\text { financing. }\end{array}$ & $\begin{array}{l}\text { Amount invested by } \\
\text { beneficiaries in } R \& D\end{array}$ & $\begin{array}{l}\text { Firm balance } \\
\text { sheets; } \\
\text { Innovation } \\
\text { surveys; } \\
\text { Industrial surveys }\end{array}$ & $\begin{array}{l}\text { Short } \\
\text { term }\end{array}$ \\
\hline $\begin{array}{l}\text { Behavioral } \\
\text { additionality }\end{array}$ & $\begin{array}{l}\text { What is the impact of the TDF on the } \\
\text { innovative behaviour of beneficiaries? The } \\
\text { evaluation assesses the effectiveness of the } \\
\text { public financing in inducing a change in the } \\
\text { behaviour of the beneficiaries and } \\
\text { increasing their capability of developing } \\
\text { process and product innovations and } \\
\text { allowing them to be more connected to the } \\
\text { National Innovation System. }\end{array}$ & $\begin{array}{l}\text { Subjective indicators } \\
\text { on product } \\
\text { innovation, process } \\
\text { innovation, linkages } \\
\text { with other agents in } \\
\text { the NIS }\end{array}$ & $\begin{array}{l}\text { Innovation } \\
\text { surveys }\end{array}$ & $\begin{array}{l}\text { Short/ } \\
\text { medium } \\
\text { term }\end{array}$ \\
\hline $\begin{array}{l}\text { Innovative } \\
\text { Outputs }\end{array}$ & $\begin{array}{l}\text { What is the impact on innovation capacity } \\
\text { of beneficiaries? Was a significant product } \\
\text { or process innovation introduced? Were } \\
\text { patents applied for? }\end{array}$ & $\begin{array}{l}\text { Patents; } \\
\text { Sales due to new } \\
\text { products }\end{array}$ & $\begin{array}{l}\text { Patents databases; } \\
\text { Innovation } \\
\text { surveys }\end{array}$ & $\begin{array}{l}\text { Short/ } \\
\text { medium } \\
\text { term }\end{array}$ \\
\hline Performance & $\begin{array}{l}\text { What is the impact on competitiveness of } \\
\text { beneficiaries - change in sales, employment, } \\
\text { productivity and a share of sales exported? } \\
\text { An innovative and efficient firm is expected } \\
\text { to be able to improve its competitiveness in } \\
\text { relation to non-beneficiaries. }\end{array}$ & $\begin{array}{l}\text { Total factor } \\
\text { productivity } \\
\text { Labor productivity; } \\
\text { Growth in sales, } \\
\text { exports, employment }\end{array}$ & $\begin{array}{l}\text { Firm balance } \\
\text { sheets; } \\
\text { Innovation } \\
\text { surveys; } \\
\text { Industrial } \\
\text { surveys; } \\
\text { Labor surveys }\end{array}$ & $\begin{array}{l}\text { Short/ } \\
\text { medium/ } \\
\text { long } \\
\text { term }\end{array}$ \\
\hline SOU & elaborations & & & \\
\hline
\end{tabular}


Table 3: Input Additionality - Testing for Crowding in / Crowding out Effects

\begin{tabular}{l|llll}
\hline & Indicator & Impact & Signif. & Conclusion \\
\hline FONTEC (CH) & R\&D intensity * & $0.74 \%$ & $10 \%$ & $\begin{array}{l}\text { Possible slight crowding out; no } \\
\text { multiplier effect }\end{array}$ \\
FONTAR-ANR (AR) & R\&D intensity * & $0.18 \%$ & $5 \%$ & $\begin{array}{l}\text { No crowding out, but no multiplier } \\
\text { effect }\end{array}$ \\
ADTEN (BR) & R\&D intensity ** & $0.66 \%$ & $5 \%$ & $\begin{array}{l}\text { Positive and significant impact, net of } \\
\text { subsidy }\end{array}$ \\
FNDCT (BR) & R\&D intensity ** & $1.63 \%$ & $5 \%$ & $\begin{array}{l}\text { Positive and significant impact, net of } \\
\text { subsidy } \\
\text { FOMOTEC (PN) }\end{array}$ \\
FONTAR-TMP I (AR) & R\&D elasticity *** & 0.28 & $5 \%$ & $\begin{array}{l}\text { No crowding out } \\
\text { Rositive and significant impact, net of } \\
\text { subsidy }\end{array}$ \\
\hline
\end{tabular}

* Difference-in-Difference [(Treated After-Treated Before) - (Control After - Control Before)] with Propensity Score Matching; R\&D variable is gross of public subsidy.

** Single difference [Treated After - Control After] with Propensity Score Matching; R\&D variable is net of public subsidy.

*** Panel Data Fixed Effects. Available data do not allow us to test for the presence of a multiplier effect. **** Panel Data Fixed Effects and Instrumental Variable; R\&D variable is net of public subsidy.

Source: Authors' elaboration on the basis of IDB (2007).

Table 4: Innovative Output and Behavioral Changes

\begin{tabular}{l|cccc}
\hline Indicator & $\begin{array}{l}\text { Impact } \\
\text { FONTEC }(\mathrm{CH}) *\end{array}$ & $\begin{array}{l}\text { Signif- } \\
\text { icance }\end{array}$ & $\begin{array}{l}\text { Impact } \\
\text { FOMOTEC }(\text { PN })^{*}\end{array}$ & $\begin{array}{l}\text { Signif- } \\
\text { icance }\end{array}$ \\
\hline $\begin{array}{l}\text { Product innovation } \\
\text { (strategic relevance on a 1-5 scale) }\end{array}$ & -1.45 & $\mathrm{NS}$ & 0.08 & $5 \%$ \\
$\begin{array}{l}\text { Process innovation } \\
\text { (strategic relevance on a 1-5 scale) }\end{array}$ & 0.46 & $10 \%$ & 0.10 & $5 \%$ \\
$\begin{array}{l}\text { Financial access } \\
\text { (improvement on a 1-5 scale) }\end{array}$ & 0.13 & $10 \%$ & 0.15 & $1 \%$ \\
$\begin{array}{l}\text { Training \& org. activities } \\
(1-5 \text { scale) }\end{array}$ & -0.06 & $\mathrm{NS}$ & 0.05 & $\mathrm{NS}$ \\
$\begin{array}{l}\text { Use of external sources of } \\
\text { knowledge (1-5 scale) }\end{array}$ & 0.10 & $5 \%$ & 0.07 & $5 \%$ \\
\hline
\end{tabular}

Single difference [Treated After - Control After] with propensity score matching.

Source: Authors' elaboration on the basis of IDB (2007). 
Table 5: Innovative Output

\begin{tabular}{l|llll}
\hline & Indicator & Impact & Signif. & Conclusion \\
\hline FONTEC (CH) & $\begin{array}{l}\text { Number of new patents, } \\
1998-2002 *\end{array}$ & 0.15 & NS & $\begin{array}{l}\text { Positive, but not significant } \\
\text { impact }\end{array}$ \\
& $\begin{array}{l}\text { Number of new } \\
\text { products, 1998-2002* } \\
\text { Sales of new products } \\
\text { (1000s of pesos), 2001- }\end{array}$ & -1.15 & NS & $\begin{array}{l}\text { Negative, but not significant } \\
\text { impact }\end{array}$ \\
FONTAR-ANR (AR) & NS & $\begin{array}{l}\text { Positive, but not significant } \\
\text { impact }\end{array}$ \\
ADTEN (BR) & $\begin{array}{l}\text { Number of patents, } \\
1996-2003^{*} \\
\text { Share of sales of new } \\
\text { FOMOTEC (PN) }\end{array}$ & 0.87 & NS & $\begin{array}{l}\text { Positive, but not significant } \\
\text { impact }\end{array}$ \\
FNDCT (BR) & $\begin{array}{l}\text { Number of patents, } \\
1999-2003 * \\
\text { Patent applications, } \\
1999-2003^{* *}\end{array}$ & -1.35 & NS & $\begin{array}{l}\text { Negative, but not significant } \\
\text { impact }\end{array}$ \\
\hline
\end{tabular}

* Difference-in-Difference [(Treated After - Treated Before) - (Control After - Control Before)] with Propensity Score Matching

** Difference-in-Difference [(Treated After - Treated Before) - (Control After - Control Before)]

Source: Authors' elaboration on the basis of IDB (2007).

Table 6: Performance

\begin{tabular}{l|llll}
\hline & Indicator & Impact & Signif. & Conclusion \\
\hline \multirow{2}{*}{ FONTEC $(\mathrm{CH})$} & Employment $(\Delta \%)^{*}$ & $3.1 \%$ & NS & Positive, but not significant impact \\
& Sales $(\Delta \%)^{*}$ & $39.6 \%$ & $10 \%$ & Positive and significant impact \\
& Productivity $(\Delta \%)^{*}$ & $24.9 \%$ & NS & Positive, but not significant impact \\
& Exports $(\%$ of sales)* & $2.7 \%$ & $10 \%$ & Positive and significant impact \\
\hline FONTAR-ANR (AR) & Employment $(\Delta \%)^{*}$ & $1.5 \%$ & NS & Positive, but not significant impact \\
& Sales $(\Delta \%)^{*}$ & $11.5 \%$ & NS & Positive, but not significant impact \\
& Productivity $(\Delta \%)^{*}$ & $-85.4 \%$ & NS & Negative, but not significant impact \\
& Exports $(\%$ of sales)* & $-0.1 \%$ & NS & Negative, but not significant impact \\
\hline ADTEN (BR) & Employment $(\Delta \%)^{*}$ & $79.0 \%$ & $1 \%$ & Positive and significant impact \\
& Sales $(\Delta \%)^{*}$ & $64.0 \%$ & $5 \%$ & Positive and significant impact \\
& Productivity $(\Delta \%)^{*}$ & $-1.0 \%$ & NS & Negative, but not significant impact \\
\hline FOMOTEC (PN) & Sales** & 2.57 & NS & Positive, but not significant impact \\
& Productivity $(\Delta \%)^{* *}$ & 0.14 & $5 \%$ & Positive and significant impact \\
& Exports** & 41.87 & NS & Positive, but not significant impact \\
\hline FNDCT (BR) & Employment $(\Delta \%)^{*}$ & $12.0 \%$ & NS & Positive, but not significant impact \\
& Sales $(\Delta \%)^{*}$ & $20.0 \%$ & NS & Positive, but not significant impact \\
& Productivity $(\Delta \%)^{*}$ & $27.5 \%$ & NS & Positive, but not significant impact \\
\hline
\end{tabular}

* Difference-in-Difference [(Treated Before-Treated After) - (Control Before - Control After)] with Propensity Score Matching

** Panel fixed effects; amount of subsidy rather than a dummy on the right hand side.

All "after" indicators are measured two years after the receipt of the subsidy.

Source: Authors' elaboration on the basis of IDB (2007). 


\section{Appendix A}

Figure A1. R\&D Input and Output: Evolution of the Gap between LAC and US (1991-2003).

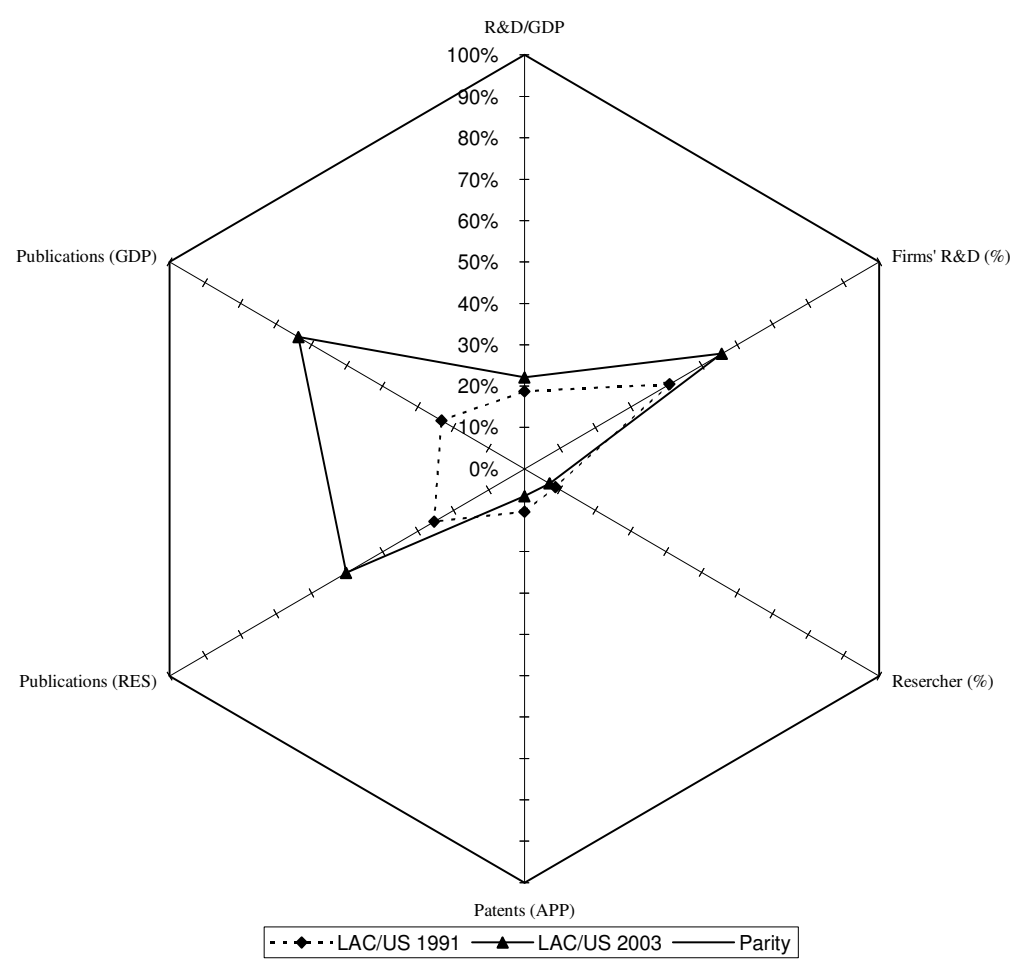

Source: Authors' elaboration on the basis of RICYT 
Table A1 - Knowledge Divide between LAC and G7 (2003 and change 1995 - 2003)

\begin{tabular}{|c|c|c|c|c|c|c|c|c|c|c|}
\hline & \multicolumn{2}{|c|}{ KEI (1) } & \multicolumn{2}{|c|}{ EIR (2) } & \multicolumn{2}{|c|}{ INN (3) } & \multicolumn{2}{|c|}{ EDU (4) } & \multicolumn{2}{|c|}{ ICT (5) } \\
\hline & GAP* & $\Delta^{* *}$ & GAP* & $\Delta * *$ & GAP* & $\Delta^{* *}$ & GAP* & $\Delta^{* *}$ & GAP* & $\Delta^{* *}$ \\
\hline Latin America & 52.5 & -2.7 & 50.4 & -9.6 & 48.9 & -3.4 & 49.5 & 1.3 & 61.2 & 0.1 \\
\hline Argentina & 64.1 & -4.7 & 35.4 & -36.5 & 68.8 & 2.5 & 87.3 & 15.8 & 63.0 & -2.7 \\
\hline Barbados & 70.8 & 14.3 & 72.0 & 32.3 & 36.5 & -2.6 & 91.2 & 11.0 & 85.1 & 19.6 \\
\hline Bolivia & 42.3 & -1.1 & 54.3 & -23.1 & 18.3 & 4.5 & 64.0 & 18.1 & 34.8 & -5.3 \\
\hline Brazil & 60.8 & 7.7 & 54.5 & -4.5 & 57.3 & 6.4 & 65.9 & 22.9 & 65.4 & 5.6 \\
\hline Chile & 80.8 & 9.7 & 112.4 & 24.2 & 64.6 & 3.0 & 73.6 & 7.9 & 75.4 & 4.6 \\
\hline Colombia & 45.7 & -5.6 & 40.2 & -17.8 & 37.4 & 1.8 & 51.9 & 1.2 & 53.3 & -8.7 \\
\hline Costa Rica & 65.1 & -2.4 & 77.3 & 3.8 & 61.1 & 1.0 & 49.4 & -10.3 & 73.8 & -3.8 \\
\hline Dominican Rep. & 36.3 & -2.6 & 42.4 & 12.4 & 3.5 & -28.7 & 47.3 & -0.4 & 53.4 & 8.5 \\
\hline Ecuador & 38.0 & -1.5 & 30.4 & -15.9 & 29.1 & 15.5 & 44.5 & -4.8 & 48.1 & -1.7 \\
\hline El Salvador & 42.8 & -0.4 & 66.9 & 4.0 & 19.4 & -2.5 & 36.7 & -1.9 & 50.8 & -0.3 \\
\hline Guatemala & 28.6 & 9.1 & 46.5 & 20.0 & 5.8 & -2.2 & 25.5 & 0.5 & 38.6 & 19.2 \\
\hline Haiti & 17.6 & 7.7 & 26.0 & 22.4 & 0.9 & 0.0 & 13.9 & 0.7 & 30.4 & 8.8 \\
\hline Honduras & 26.1 & -7.5 & 39.4 & 7.6 & 10.7 & -25.5 & 28.3 & -1.2 & 27.3 & -9.4 \\
\hline Jamaica & 58.2 & -0.3 & 51.8 & -13.6 & 55.3 & -15.0 & 50.8 & 6.3 & 74.2 & 20.3 \\
\hline Mexico & 59.7 & 0.4 & 68.1 & -7.2 & 55.3 & 3.0 & 51.5 & 2.3 & 64.7 & 2.4 \\
\hline Nicaragua & 30.5 & 5.6 & 51.4 & 31.5 & 8.4 & 2.1 & 33.6 & -0.1 & 30.7 & -8.6 \\
\hline Paraguay & 31.9 & -4.5 & 30.9 & -28.4 & 8.4 & 3.6 & 49.1 & 6.8 & 40.3 & -1.2 \\
\hline Peru & 49.4 & 1.9 & 46.7 & 3.4 & 38.0 & -0.3 & 59.9 & -0.4 & 53.2 & 5.9 \\
\hline Uruguay & 64.1 & -7.6 & 72.4 & -13.8 & 35.2 & -21.1 & 82.8 & 8.1 & 67.9 & -3.0 \\
\hline Venezuela & 46.2 & -8.7 & 13.3 & -30.9 & 51.5 & -3.0 & 61.3 & 7.1 & 56.4 & -9.3 \\
\hline
\end{tabular}

Notes to table:

* GAP $=[($ Value for the country $i) /($ Value for G7) $]$;

$* * \Delta=\left[\mathrm{GAP}_{2003}-\mathrm{GAP}_{1995}\right]$

(1) KEI = Knowledge Economy Index

(2) $\mathrm{EIR}=$ Economic Incentive and Institutional Regime

(3) INN = Innovation System

(4) $\mathrm{EDU}=$ Education

(5) ICT = Information and Communication Technologies.

Source: World Bank K4D 
Table A2 - Overview of the Case Studies

\begin{tabular}{|c|c|c|c|}
\hline Method & Impact variable & Covariates * & Interpretation of the impact \\
\hline \multicolumn{4}{|c|}{ 1. Country and Period: Argentina 1994-2001; Program name: FONTAR-TMP I; Data type: Panel; No. of Obs.: 420 x 7; Period of exposure: $1995-2001$} \\
\hline $\mathrm{FE}^{* *}+\mathrm{IV}$ & R\&D elasticity (net of subsidy) & $\begin{array}{l}\text { Sales, employment, exports, ratio of qualified } \\
\text { employees to the total employees } \\
\text { Additional inst. = } \mathrm{N} \text { of offices promoting program } \\
\text { located in the province of the firm. }\end{array}$ & $\begin{array}{l}\text { Fixed effects, instrumented. The impact is the within firm elasticity of } \\
\text { R\&D with respect to the subsidy. }\end{array}$ \\
\hline \multicolumn{4}{|c|}{ 2. Country and Period: Argentina 2001-2004; Program name: FONTAR-ANR; Data type: Panel; No. of Obs.: 414 x 4; Period of exposure: $2002-2004$} \\
\hline $\begin{array}{l}\text { DD with } \\
\text { PSM }^{* * *}\end{array}$ & $\begin{array}{l}\text { R\&D intensity change (gross of subsidy) } \\
\text { Sales of new products (1000s of pesos) }(\Delta, \\
2001-2004) \\
\text { Employment }(\Delta \%, 2001-2004) \\
\text { Sales }(\Delta \%, 2001-2004) \\
\text { Productivity }(\Delta \%, 2001-2004) \\
\text { Export share of sales }(\Delta, 2001-2004)\end{array}$ & $\begin{array}{l}\text { Group, sales, the ratio of qualified employees to } \\
\text { number of employees, economic sector, location }\end{array}$ & $\begin{array}{l}\text { Difference in difference with propensity score matching. The impact } \\
\text { is the average difference of the changes in the variables between } \\
\text { treated and untreated firms that have been matched using the } \\
\text { propensity score. }\end{array}$ \\
\hline \multicolumn{4}{|c|}{ 3. Country and Period: Brazil 1996-2003; Program name: ADTEN; Data type: Panel; No. of Obs.: 11,645 x 8; Period of exposure: 1997-2003 } \\
\hline $\begin{array}{l}\text { D with } \\
\text { PSM *** }\end{array}$ & R\&D intensity (net of subsidy, 2000) & $\begin{array}{l}\text { Sales, firm's solvency (dummies), firm's age, } \\
\text { market share, foreign capital (dummy), exporting } \\
\text { firm (dummy), economic sector, location }\end{array}$ & $\begin{array}{l}\text { Differences with propensity score matching. The impact is the average } \\
\text { difference of } R \& D \text { intensity between treated and untreated firms that } \\
\text { have been matched using the propensity score. }\end{array}$ \\
\hline $\begin{array}{l}\text { DD with } \\
\text { PSM }^{* * *}\end{array}$ & $\begin{array}{l}\text { Number of patents }(\Delta, 1996-2003) \\
\text { Employment }(\Delta \%, 1996-2003) \\
\text { Sales }(\Delta \%, 1996-2003) \\
\text { Productivity }(\Delta \%, 1996-2003)\end{array}$ & $\begin{array}{l}\text { Sales, firm's solvency (dummies), firm's age, } \\
\text { market share, foreign capital (dummy), exporting } \\
\text { firm (dummy), economic sector, location }\end{array}$ & $\begin{array}{l}\text { Difference in difference with propensity score matching. The impact } \\
\text { is the average difference of the changes in the variables between } \\
\text { treated and untreated firms that have been matched using the } \\
\text { propensity score. }\end{array}$ \\
\hline \multicolumn{4}{|c|}{ 4. Country and Period: Brazil 1999-2003; Program name: FNDCT; Data type: Panel; No. of Obs.: 15,466 x 5; Period of exposure: $1999-2003$} \\
\hline $\begin{array}{l}\text { D with } \\
\text { PSM *** }\end{array}$ & R\&D Intensity (net of subsidy, 2003) & & $\begin{array}{l}\text { Differences with propensity score matching. The impact is the average } \\
\text { difference of } R \& D \text { intensity between treated and untreated firms that } \\
\text { have been matched using the propensity score. }\end{array}$ \\
\hline $\begin{array}{l}\text { DD with } \\
\text { PSM }^{* * *}\end{array}$ & $\begin{array}{l}\text { Number of patents }(\Delta, 1996-2003) \\
\text { Patent applications }(\Delta, 1996-2003) \\
\text { Employment }(\Delta \%, 1996-2003) \\
\text { Sales }(\Delta \%, 1996-2003) \\
\text { Productivity }(\Delta \%, 1996-2003)\end{array}$ & $\begin{array}{l}\text { Sales, firm's solvency (dummies), firm's age, } \\
\text { market share, foreign capital (dummy), exporting } \\
\text { firm (dummy), economic sector, location }\end{array}$ & $\begin{array}{l}\text { Difference in difference with propensity score matching. The impact } \\
\text { is the average difference of the changes in the variables between } \\
\text { treated and untreated firms that have been matched using the } \\
\text { propensity score. }\end{array}$ \\
\hline
\end{tabular}




\begin{tabular}{|c|c|c|c|}
\hline Method & Impact variable & Covariates * & Interpretation of the impact \\
\hline \multicolumn{4}{|c|}{ 5. Country and Period: Chile 1998-2002; Program name: FONTEC; Data type: Panel; No. of Obs.: 439 x 4; Period of exposure: $1999-2001$} \\
\hline $\begin{array}{l}\text { DD with } \\
\text { PSM *** }\end{array}$ & $\begin{array}{l}\text { R\&D intensity (gross of public subsidy) } \\
\text { Number of patents }(\Delta, 1998-2002) \\
\text { No. of new products }(\Delta, 1998-2002) \\
\text { Employment }(\Delta \%, 1998-2002) \\
\text { Sales }(\Delta \%, 1998-2002) \\
\text { Productivity }(\Delta \%, 1998-2002) \\
\text { Export share of sales }(\Delta, 1998-2002)\end{array}$ & \multirow[t]{2}{*}{$\begin{array}{l}\text { Sales, firm's age, firm's age square, economic } \\
\text { sector }\end{array}$} & $\begin{array}{l}\text { Difference in difference with propensity score matching. The impac } \\
\text { is the average difference of the changes in the variables betweer } \\
\text { treated and untreated firms that have been matched using the } \\
\text { propensity score. }\end{array}$ \\
\hline $\begin{array}{l}\text { D with } \\
\text { PSM *** }\end{array}$ & $\begin{array}{l}\text { Product innovation (relevance, } 1-5 \text { scale) } \\
\text { Process innovation (relevance, } 1-5 \text { scale) } \\
\text { Financial access (relevance, } 1-5 \text { scale) } \\
\text { Training \& org. ( } 1-5 \text { scale) } \\
\text { Use of external knowledge ( } 1-5 \text { scale) }\end{array}$ & & $\begin{array}{l}\text { Differences with propensity score matching. The impact is the average } \\
\text { difference of the variables between treated and untreated firms tha } \\
\text { have been matched using the propensity score. }\end{array}$ \\
\hline \multicolumn{4}{|c|}{ 6. Country and Period: Panama 2000-2003; Program name: FOMOTEC; Data type: Panel; No. of Obs.: 179 x 4; Period of exposure: 2001-2003 } \\
\hline $\begin{array}{l}\text { FE } \\
\text { PSM with } \\
\text { common } \\
\text { support }\end{array}$ & $\begin{array}{l}\text { R\&D elasticity (net of subsidy) } \\
\text { Sales elasticity } \\
\text { Productivity elasticity } \\
\text { Export elasticity } \\
\text { Share of sales of new products (2000-2003) }\end{array}$ & $\begin{array}{l}\text { FE: Sales, ratio export sales, average salary, year } \\
\text { dummies } \\
\text { PSM: Export share, total employment, firm's age, } \\
\text { investment in machinery, economic sector }\end{array}$ & $\begin{array}{l}\text { Fixed effects. The impact is the within firm elasticity of the left hanc } \\
\text { variable with respect to the subsidy. }\end{array}$ \\
\hline $\begin{array}{l}\text { D with } \\
\text { PSM *** }\end{array}$ & $\begin{array}{l}\text { Product innovation (relevance, } 1-5 \text { scale) } \\
\text { Process innovation (relevance, } 1-5 \text { scale) } \\
\text { Financial access (relevance, } 1-5 \text { scale) } \\
\text { Training \& org. activities }(1-5 \text { scale) } \\
\text { Use of external knowledge }(1-5 \text { scale) }\end{array}$ & $\begin{array}{l}\text { Ratio export sales, total employment, firm's age, } \\
\text { investment in machinery, economic sector }\end{array}$ & $\begin{array}{l}\text { Differences with propensity score matching. The impact is the average } \\
\text { difference of the variables between treated and untreated firms. }\end{array}$ \\
\hline
\end{tabular}

Notes: FE = Fixed effect; D = Difference (compares levels); DD = Difference in Difference (compares growth rates); PSM = Propensity Score Matching; IV = Instrumental Variable

* In the case of FE models, this column gives the right hand side variables included. For PSM it gives the variables included in the propensity score, which is computed using the values in the year before the subsidy began.

** The impact was calculated through a fixed effect estimation of the following model:

$\log \left(y_{i t}\right)=\beta_{1} * \log (x)_{i t}+\beta_{2} * \log \left(S_{i t}\right)+\beta_{3} * \theta_{t}+\gamma_{i}+\varepsilon_{i t}$

where $y_{i t}$ is the level of private R\&D investment in innovation of firm $i$ in year $\mathrm{t}, x_{i t}$ is a vector of observable covariates, $S_{i t}$ is the actual amount received through the program, $\theta_{t}$ denotes year dummies; $\gamma_{i}$ is a firm-specific component common to all firms and $\varepsilon_{i t}$ is an i.i.d. zero mean random variable assumed to be independent of $x_{i t}$

*** The impact was estimated as average effect of the treatment on the treated (ATT)

$A T T=E\left[E\left(Y_{1} \mid D=1, \mathrm{p}(x)\right)-E\left(Y_{0} \mid D=0, \mathrm{p}(x)\right) \mid D=1\right]$

where $Y$ is the impact variable, $D=\{0,1\}$ is a dummy variable for the participation in the program, $x$ is a vector of pretreatment characteristics and $p(x) \equiv P(D=1 \mid x)=E(D \mid x)$ is the propensity score. In the case of $\mathrm{DD}$, the impact variable is a growth rate (the change in $\log Y$ ) or a difference $(\Delta Y)$. 